\title{
THE GENETIC AND NON-GENETIC AFFECT ON CARCASS CHARACTERISTICS OF NEW ZEALAND WHITE AND BALADI BLACK RABBITS
}

التأثير الوراثي وغير الوراثي على خصائص الأبيحة في أرانب النيوزيلندي الأبيض

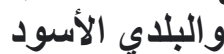

By

Amira S.El-Deighadi; M. G. Gharib; M.I seif EL-Nasr; Yonan G. E. Mogda M. Salem and Lamia F. Abdel Mawla Animal Production Research Institute, Agriculture Research Center, Dokki, Cairo, Egypt (APRI).

Doi: 10.21608/asajs.2021.179614

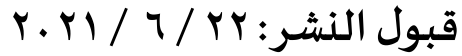

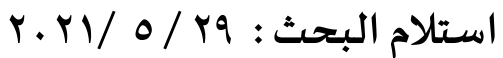

El-Deighadi , Amira S.; Gharib , M. G.; seif EL-Nasr, M.I; Yonan, G. E. Salem, Mogda M. \& Mawla ,Lamia F. Abdel (2021). Arab Journal of Agriculture Sciences, AIESA.(4),11, pp 141 - 162. 


\section{ABSTRACT:}

Data collected on 120random male at 12 weeks of age, from New Zealand white and Baladi Black rabbit. Data were analyzed applying multi-trait animal model ofcarcass characteristicsto obtain proportion of the phenotypic variance due to additive genetic effects $\left(\mathrm{h}^{2}\right)$; common litter effects $\left(\mathrm{c}^{2}\right)$; random error effects $\left(\mathrm{e}^{2}\right)$; genetic $\left(\mathrm{r}_{\mathrm{G}}\right)$, common litter $\left(\mathrm{r}_{\mathrm{C}}\right)$, environmental $\left(\mathrm{r}_{\mathrm{E}}\right)$ and phenotypic $\left(\mathrm{r}_{\mathrm{P}}\right)$ correlations.Datawere carried out by weighed least-squares means method in the procedure GLM of statistical software SAS(2003) to obtain least squares of effects for breed, parity and season and significant. Heritability estimateswere mostly moderate $0.20,0.12$ and 0.37 for live weight at slaughter, weight after bleedingand weight with viscera and without head,were moderate and high and ranged from 0.29 to 54 for edible parts, were moderate and ranged from 0.30 to 0.35 for dressing yield, alsowere low and moderate and ranged from 0.03 to 0.33 for inedible parts.Common litter effects Estimates were 0.37, 0.55 and 0.55 for live weight at slaughter, weight after bleedingand weight with viscera and without head, were ranged from 0.28 to 0.60 for edible parts, were estimates ranged from 0.38 to 0.42 for dressing yield and ranged from 0.42 to 0.55 inedible parts.All possible genetic correlations betweencarcasscharacteristics were moderate to highandpositive except among TEDand both of LU and FUR, also between DR1 and VIS were negative.Common litter correlationsamongrecords ofcarcasscharacteristicswere mostly moderate or high, positiveand negative.Correlations ofenvironmental betweencarcasscharacteristicswere mostly moderate or high, positive and negative. Estimates of $\left(\mathrm{r}_{\mathrm{P}}\right)$ between records of different carcasscharacteristicswere mainly positive and moderate or high magnitude. No significant differences of breed on carcass characteristics except for giblet. New Zealand White had highest of giblet and leaver. In mostly 
parity affected significantly on carcass characteristics, the highest value during first parity except for giblet and leaver were highest value during second parity. Contrary other traits were insignificantly.Most carcass characteristics were higher in winter months than other seasons.

Key words: Edible parts, dressing yield \%, inedible parts, heritability, genetic and phenotypic correlations.

\section{المستخلص : - | (الم}

تم تحليل البيانات باستخدام برنامج النموذج الحيواني بطريقة معظمة

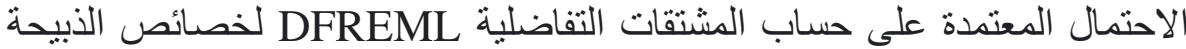

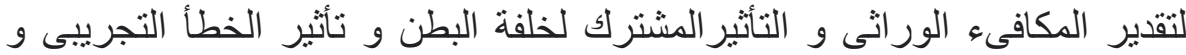

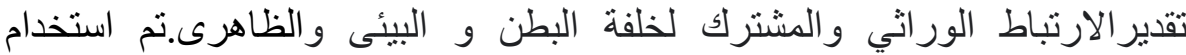

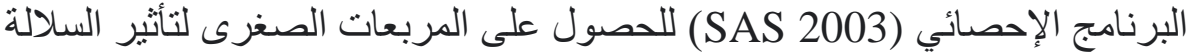

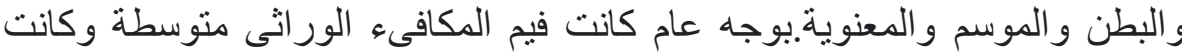

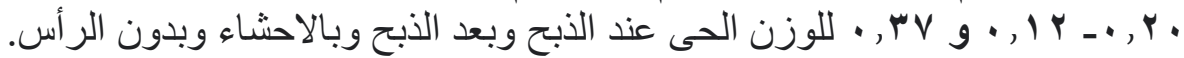

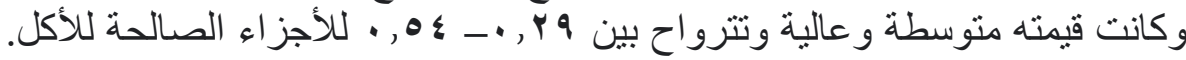

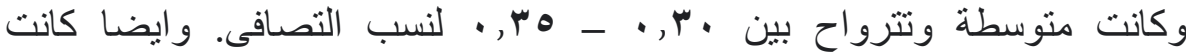

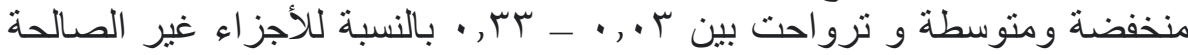

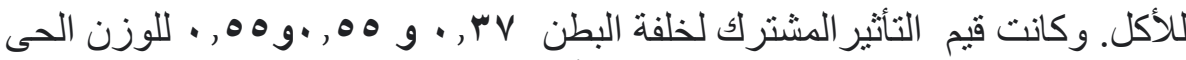

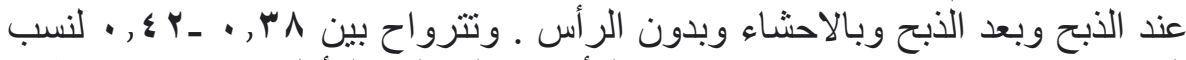

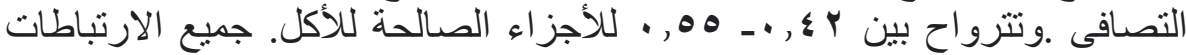

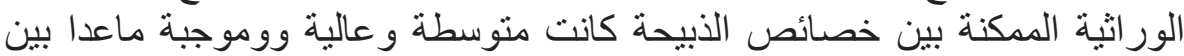

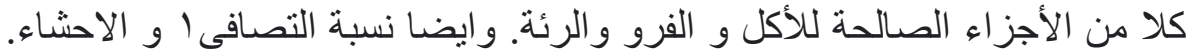

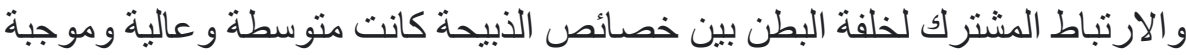

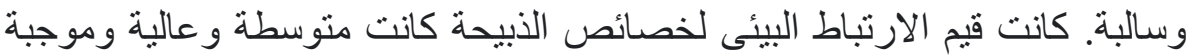

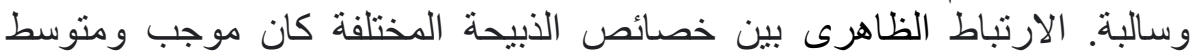

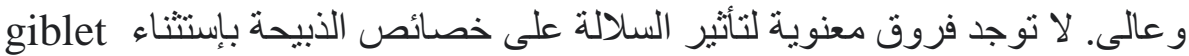

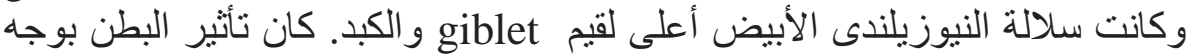

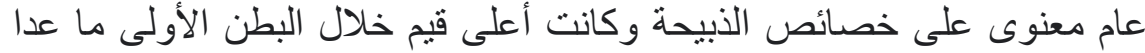
giblet خصائص الأبيحة أعلى فى الثتاء عن البـ المول اسم الأخرى. 


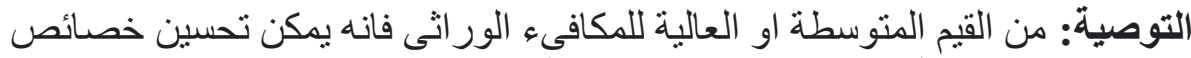

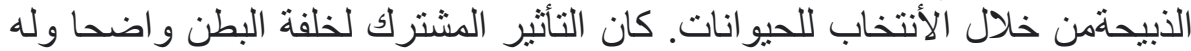

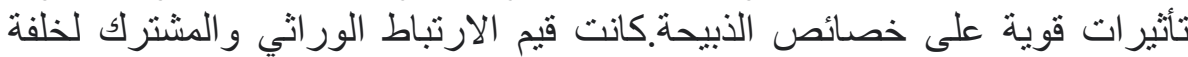

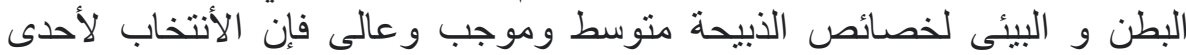

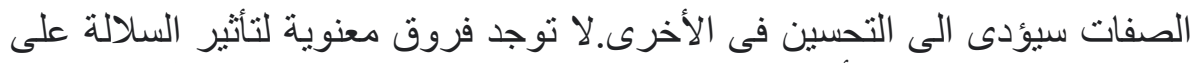

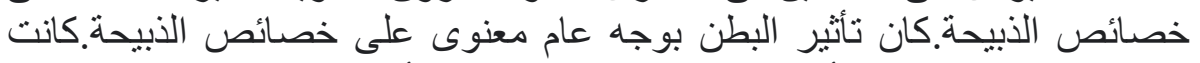

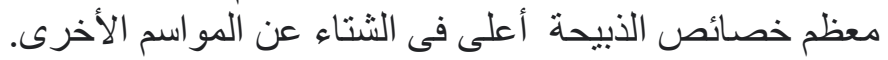

\section{INTRODUCTION:}

Production of rabbit has an important role in bridging shortage of food in many countries Khalil et al.,(2016). For meat ofRabbit has several advantages including high protein content and low cholesterol content Hanaa et al.,(2014). The quality attributes of food products including rabbit meat have been attracting an increasing interest in recent years. Meat products from ecological rearing were characterized by a higher nutritive quality and better taste Horsted et al.,(2010).In addition rabbit has a quite high dressing percentage when compared to ruminants, ranging between 50 - 65\% (Lebas et al., 1986andRoiron et al., 1992). Heritability of different carcass traits is medium to high, and therefore carcass traits might be considered in rabbit selection and breeding, however it has been reported that different factors, such as age at slaughter, weight at slaughter, breed, and sex, have an influence on different carcass traits (ParigiBini et al., 1992; Bianospino et al., 2006; Gašperlin et al., 2006and Metzgeret al., 2006). The purpose of this study is to estimate of heritability, common litter effects, and genetic, common litter, environmental and phenotypic using multi-trait animal to determine the suitability of selection for achieving genetic improvement.Also discuss some non-genetic that affect carcass characteristicsfor New Zealand white and Baladi Black rabbits. Hence, an effort was made to find the effects of different 
factors on the carcass characteristicsfor obtaining maximum dressed meat and dressing yield.

\section{MATERIALS AND METHODS:}

\section{Animals and data:}

This study was carried out at Sakha Animal Farm, Animal Production Research Institute, Agricultural Research Center, Dokki, Egypt (APRI). Data collected on 120random maleat 12 weeks of age, from New Zealand white and Baladi Black rabbit.

\section{Slaughtering procedure:}

All rabbits were weighed and slaughtered. Each rabbit was bled and weighed to determine the blood weight. Fur was removed and weighed after slaughter. Head was separated and the internal organs were also removed and weighed.Furwith tail and feet and other inedible parts were also measured with a sensitive scale. Data collection as followed; Pre-slaughter weight(g) was the live weight of each rabbit before slaughter in grammars; Hot carcass (g) was the weight after slaughter and bleeding of rabbit; Giblets(g) were total weight of kidney, liver and heart; Inedible carcass $(\mathrm{g})$ were total weight of lung, furwith tail and feet,viscera, blood, ;Edible carcass $(g$, dressed head and giblet. Dressing yield (\%)was taken as the percentage of edible carcass to the pre-slaughter weight.

\section{The statistical analysis:}

The variances and covariances were obtained using REML method of VARCOMP procedure of SAS 2003. Data were analyzed applying multi-trait animal model of carcass characteristics applying MTDFREML programs of Boldmanet al.,1995, to obtain

Starting mixed model was obtained applying REML method of VARCOMP procedure of SAS 2003. Data were analyzed using multi-trait animal model of carcass characteristicsusing MTDFREML programs of Boldman et al.,1995, to obtain 
proportion of the phenotypic variance due to additive genetic effects $\left(h^{2}\right)$; common litter effects $\left(c^{2}\right)$; random error effects $\left(\mathrm{e}^{2}\right)$; genetic $\left(\mathrm{r}_{\mathrm{G}}\right)$, common litter $\left(\mathrm{r}_{\mathrm{C}}\right)$, environmental $\left(\mathrm{r}_{\mathrm{E}}\right)$ and phenotypic $\left(\mathrm{r}_{\mathrm{P}}\right)$ correlations. Analyses were done according to the general model:

$$
\mathbf{y}=\mathbf{X b}+\mathbf{Z}_{1} \mathbf{a}+\mathbf{Z}_{2} \mathbf{p}+\mathbf{e} \text {. (Model 1) }
$$

Where, $y=$ Vector of observation, $X=$ Incidence matrix of fixed effects; $\mathrm{b}=$ vector of fixed effects including breed, (NZW and $\mathrm{BB})$, parity (3 levels) and season (4 levels); $\mathrm{Z}_{1}$ and $\mathrm{Z}_{2}=$ incidence matrices corresponding to random effects of additive (a) and common litter effect $\left(\mathrm{r}_{\mathrm{C}}\right)$ respectively.

Datawere carried out by weighed least-squares means method in the procedure GLM of statistical software SAS(2003) to obtain least squares and used to compare means by Duncan's multiple range test for carcass characteristics.

Where:

$$
\mathbf{Y}_{\mathrm{ijk}}=\mu+\mathrm{B}_{\mathrm{i}}+\mathrm{P}_{\mathrm{j}}+\mathrm{S}_{\mathrm{k}}+\mathrm{e}_{\mathrm{ijk}} \cdot \quad \text { (Model2). }
$$

$\mathrm{Y}_{\mathrm{ijk}}=$ the parameters on the $\mathrm{ijk}^{\text {th }}$ carcass characteristics, $\mu=$ the overall mean, $B_{i}=$ the fixed effect of the $i^{\text {th }}$ breeds ( $i=N Z W$ and $B B) ; P_{j}=$ the fixed effect of the $j^{\text {th }}$ parity $(j=1,2$ and 3$) ; S_{k}=$ the fixed effect of the $\mathrm{k}^{\text {th }}$ season $(\mathrm{k}=1,2,3$ and 4$)$ and $\mathrm{e}_{\mathrm{ijk}}=$ the random deviation of all the other effects no specified the model.

\section{Results and Discussion:}

Genetic affect:

Heritability estimates

Heritability estimates for carcass characteristics in (Table 1). The estimateswere mostly moderate $0.20,0.12$ and 0.37 for live weight at slaughter, weight after bleedingand weight with viscera and without head. The estimates were moderate and high and ranged from 0.29 to 54 for edible parts. The estimates were moderate and ranged from 0.30 to 0.35 for dressing yield. The estimates were low and moderate and ranged from 0.03 to 0.33 for inedible parts. Ayyat et al., (1994) with NZW rabbits, 
Heritability were low to moderatefor non-edible carcass traits. Ferraz and Eler, (1996) found moderate estimates of heritability for carcass weight andcarcass yield of 0.178 and 0.152 for the Californian breed and 0.152 and 0.000 for NZW rabbits, respectively. Khalil et al., (2005) reported heritability estimates for hot carcass weight, offal weight and meat weight were moderate and ranged 0.10 to 0.16 but low for dressing percent (0.097). Al Seaf et al., (2007) reported heritability estimates for edible and non-edible carcasswere mostly moderateand ranged from 0.12 to 0.22 .Garreau et al., (2008) reported that heritability estimates for carcass yield were moderate $(0.24)$. 
Table 1: Estimates for proportion of the phenotypic variance due to additive genetic effects $\left(h^{2}\right)$ and to common litter effects $\left(\mathrm{c}^{2}\right)$ and to random error effects $\left(\mathrm{e}^{2}\right)$ with standard errors $( \pm \mathrm{SE})$ for carcass characteristicsfor New Zealand white (NZW) and Baladi Black (BB) rabbits.

\begin{tabular}{lccc}
\hline Arameters & $\mathbf{h}^{2}$ & $\mathbf{c}^{2}$ & $\mathbf{e}^{2}$ \\
\hline $\begin{array}{l}\text { Live weight, at slaughter, g } \\
\text { Weight after bleeding, g }\end{array}$ & $0.20 \pm 0.03$ & $0.37 \pm 0.06$ & $0.43 \pm 0.09$ \\
Weight with viscera and without & $0.12 \pm 0.02$ & $0.55 \pm 0.07$ & $0.33 \pm 0.05$ \\
head, g & & $0.54 \pm 0.08$ & $0.08 \pm 0.1$ \\
Edible parts: & & & \\
Hot carcass without head, g & $0.29 \pm 0.11$ & $0.60 \pm 0.09$ & $0.11 \pm 0.02$ \\
Giblet, g & $0.41 \pm 0.06$ & $0.52 \pm 0.08$ & $0.07 \pm 0.14$ \\
Head, g & $0.38 \pm 0.10$ & $0.53 \pm 0.08$ & $0.11 \pm 0.02$ \\
Total edible, g & $0.54 \pm 0.07$ & $0.28 \pm 0.04$ & $0.17 \pm 0.03$ \\
Dressing yield \%: & & & \\
Carcass \% & $0.31 \pm 0.11$ & $0.42 \pm 0.06$ & $0.27 \pm 0.04$ \\
Carcass with giblet \% & $0.30 \pm 0.11$ & $0.39 \pm 0.06$ & $0.30 \pm 0.05$ \\
Carcass with giblet and head \% & $0.35 \pm 0.10$ & $0.38 \pm 0.06$ & $0.28 \pm 0.04$ \\
Inedible parts: & & & \\
Lung, g & $0.16 \pm 0.03$ & $0.47 \pm 0.08$ & $0.37 \pm 0.06$ \\
Fur, g & $0.33 \pm 0.05$ & $0.42 \pm 0.02$ & $0.25 \pm 0.12$ \\
Viscera, g & $0.06 \pm 0.15$ & $0.55 \pm 0.09$ & $0.39 \pm 0.06$ \\
Blood, g & $0.03 \pm 0.01$ & $0.48 \pm 0.08$ & $0.49 \pm 0.08$ \\
Total inedible & $0.11 \pm 0.14$ & $0.45 \pm 0.07$ & $0.44 \pm 0.07$ \\
Inedible : edible & $0.19 \pm 0.03$ & $0.50 \pm 0.08$ & $0.32 \pm 0.11$ \\
\hline
\end{tabular}

From these observations for moderate or high for hertabilities, it is genetic point of view improvements were achieved in carcass traits through selection of animals.

Common litter effects

Common litter effects for carcass characteristics in (Table 1)were moderate to high and were generally higher than the respective heritabilities. Estimates were 0.37, 0.55 and 0.55 for live weight at slaughter, weight after bleeding and weight with 
viscera and without head. The estimates ranged from 0.28 to 0.60 for edible parts. The estimates ranged from 0.38 to 0.42 for dressing yield. The estimates ranged from 0.42 to 0.55 inedible parts. These results agreement with Al Seaf et al., (2007) who reported common litter effects for carcass traits and ranged from 0.31 to 0.37 for slaughter and edible carcass traits, 0.29 to 0.39 for non-edible carcass traits and suggested common litter effects appeared to have strong effects on growth even up to slaughtering time. Ferrazet al.,(1992) found that common environmental effects to be consistently more important than direct genetic effects for several traits studied, but Lukefahret al., (1996) reported that for each carcass trait investigated, the magnitudes of variance components for direct genetic and common environmental effects were similar.

\section{Correlations among carcass characteristics:}

Importance of economic and biological relationships betweenstudying traits may understood in relationship to other traits. The estimates of genetic $\left(\mathrm{r}_{\mathrm{G}}\right)$, common litter $\left(\mathrm{r}_{\mathrm{C}}\right)$, environmental $\left(\mathrm{r}_{\mathrm{E}}\right)$ and phenotypic $\left(\mathrm{r}_{\mathrm{P}}\right)$ correlations are shown in Tables 2, 3, 4 and 5 .

\section{Genetic correlations $\left(r_{G}\right)$}

Generally all possible genetic correlations between carcass characteristics were moderate to highandpositive except among TEDand both of LUand FUR, also between DR1 and VIS were negative (Table 2). The higher correlations between LWBand both of WB; DR1; LU and IND: TED,also higher among WB and both of WBV; DR1; DR2, also higher among $\mathrm{HC}$ and TE, also higher among $\mathrm{G}$ and both of TE; VIS, also higher among $\mathrm{H}$ and both of DR1; BL.also higher among TED and both of B1; TIND; also higher among DR1; DR2; DR3; BL; TIND, also higher among DR2and both of DR3; FUR; TIND; IND:TEDand higher between TIND and IND: TED.From results 
selection improving LWB might be expected to improvement in all pervious traits.Su et al., (1999) found that a negative genetic correlation between post-weaning daily gain and dressing yield $(-0.22)$. Garreau et al., (2008) reported that the negative genetic correlation between 63-day body weight and dressing yield (0.24). Hanaa et al., (2014) reported that the genetic correlation between slaughter weight and weaning weight were high and positive (0.73).

Table 2: Estimates genetic correlations $\left(\mathrm{r}_{\mathrm{G}}\right)$ for carcass characteristics for (NZW) and (BB) rabbits.

\begin{tabular}{|c|c|c|c|c|c|c|c|c|c|c|c|c|c|c|c|}
\hline & WB & WBV & HC & G & H & TED & DR1 & DR2 & DR3 & LU & FUR & VIS & BL & TIND & TIND:TED \\
\hline LWB & 0.96 & 0.56 & 0.59 & 0.57 & 0.49 & 0.19 & 0.98 & 0.54 & 0.53 & 086 & 0.57 & 0.49 & 0.04 & 0.78 & 0.97 \\
\hline WB & & 0.86 & 0.76 & 0.58 & 0.44 & 0.53 & 0.88 & 0.81 & 0.62 & 0.59 & 0.51 & 0.68 & 0.62 & 0.14 & 0.78 \\
\hline WBV & & & 0.60 & 0.51 & 0.79 & 0.81 & 0.54 & 0.40 & 0.50 & 0.32 & 0.36 & 0.64 & 0.31 & 0.93 & 0.42 \\
\hline HC & & & & 0.29 & 0.34 & 0.99 & 0.62 & 0.50 & 0.50 & 0.58 & 0.68 & 0.64 & 0.42 & 0.54 & 0.46 \\
\hline $\mathbf{G}$ & & & & & 0.91 & 0.98 & 0.45 & 0.61 & 0.54 & 0.76 & 0.36 & 0.91 & 0.72 & 0.39 & 0.57 \\
\hline H & & & & & & 0.47 & 0.85 & 0.28 & 0.21 & 0.47 & 0.33 & 0.60 & 0.85 & 0.65 & 0.64 \\
\hline TED & & & & & & & 0.20 & 0.33 & 0.26 & -0.73 & 0.63 & 0.66 & 0.82 & 0.88 & 0.74 \\
\hline DR1 & & & & & & & & 0.99 & 0.99 & 0.57 & 0.17 & -0.29 & 0.89 & 0.66 & 0.80 \\
\hline DR2 & & & & & & & & & 0.99 & 0.77 & 0.98 & 0.82 & 0.93 & 0.99 & 0.99 \\
\hline DR3 & & & & & & & & & & 0.91 & 0.88 & 0.94 & 0.87 & 0.46 & 0.81 \\
\hline $\mathbf{L U}$ & & & & & & & & & & & 0.67 & 0.57 & 0.43 & 0.79 & 0.77 \\
\hline FUR & & & & & & & & & & & & 0.82 & 0.78 & 0.71 & 0.15 \\
\hline VIS & & & & & & & & & & & & & 0.73 & 0.85 & 0.87 \\
\hline BL & & & & & & & & & & & & & & 0.61 & 0.70 \\
\hline TIND & & & & & & & & & & & & & & & 0.97 \\
\hline
\end{tabular}

LWB=Live weight, at slaughter, $\mathrm{g}$; WB=Weight after bleeding, $\mathrm{g}$; WBV=Weight with viscera and without head, g; $\mathrm{HC}=\mathrm{Hot}$ carcass without head, g; G=Giblet, g; H=Head, g; TED= Total edible, g; DR1 $=$ Carcass \%; DR2 $=$ Carcass with giblet \%; DR3= Carcass with giblet and head \%; LU= Lung, g; VIS= Viscera, g; $\mathrm{B}=\mathrm{Blood} ; \mathrm{TIND}=$ Total inedible; IND:TED= Inedible $:$ edible.

\section{Common litter correlations $\left(r_{C}\right)$}

The estimates of common litter correlationsamongrecords ofcarcasscharacteristics mostly moderate or high, positive and negative (Table 3). The higher correlations amongLWB and both ofand both of WBV; HC; H; TED ; DR2; DR3 and IND: TED, also higher among WB and both of WBV; FUR and TIND, also 
higher among $\mathrm{HC}$ and TE, also higher among $\mathrm{G}$ and both of $\mathrm{H}$ TED, also higher among DR1and both of DR2; DR3; LU; BL.also higher among DR2and both of B1; TIND; also higher among DR1; DR2; DR3; BL; TIND, also higher among DR2 and both of DR3; FUR; VIS TIND, higher amongDR3 and both ofLU; FUR; VIS, higher between LU and VIS and higher between TIND and IND: TED. From resultsthe importance ofcommon litter correlationoncarcasscharacteristics becomes evident.Thus, it is necessary might recommend that these correlations should be considered in any program of breeding to improve litter traits in rabbits.No research is available for estimates of $\left(\mathrm{r}_{\mathrm{C}}\right)$ carcass characteristics in rabbits.

Table 3: Estimates common litter correlations $\left(\mathrm{r}_{\mathrm{C}}\right)$ for carcass characteristics for (NZW) and (BB) rabbits.

\begin{tabular}{|c|c|c|c|c|c|c|c|c|c|c|c|c|c|c|c|}
\hline & WB & WBV & $\mathrm{HC}$ & $\mathbf{G}$ & $\mathbf{H}$ & TED & DR1 & DR2 & DR3 & $\mathbf{L U}$ & FUR & VIS & BL & TIND & TIND:TED \\
\hline LWB & 0.72 & 0.92 & 0.93 & 0.66 & 0.94 & 0.98 & 0.41 & 0.98 & 0.80 & 0.60 & 0.64 & 0.49 & 0.61 & 0.76 & 0.96 \\
\hline WB & & 0.97 & 0.50 & 0.53 & 0.70 & 0.79 & -0.89 & -0.56 & 0.63 & 0.50 & 0.92 & 0.68 & -0.11 & 0.82 & 0.17 \\
\hline WBV & & & 0.67 & 0.28 & 0.27 & 0.73 & -0.99 & -0.98 & -0.97 & 0.54 & 0.43 & 0.62 & 0.55 & 0.58 & 0.19 \\
\hline HC & & & & 0.17 & 0.22 & 0.98 & 0.58 & 0.60 & 0.51 & 0.31 & -0.57 & -0.96 & 0.13 & -0.78 & -0.90 \\
\hline $\mathbf{G}$ & & & & & 0.93 & 0.97 & -0.89 & -0.96 & -0.71 & -0.98 & 0.34 & -0.13 & -0.72 & 0.20 & -0.37 \\
\hline H & & & & & & 0.98 & -0.97 & -0.98 & -0.84 & -0.18 & 0.38 & 0.21 & -0.13 & 0.25 & -0.45 \\
\hline TED & & & & & & & 0.76 & 0.54 & 0.56 & 0.63 & 0.76 & 0.41 & -0.97 & 0.74 & 0.67 \\
\hline DR1 & & & & & & & & 0.98 & 0.99 & 0.94 & -0.98 & -0.89 & 0.98 & 0.77 & 0.48 \\
\hline DR2 & & & & & & & & & 0.98 & 0.50 & 0.80 & 0.90 & -0.34 & 0.99 & -0.99 \\
\hline DR3 & & & & & & & & & & 0.91 & 0.91 & 0.88 & -0.50 & 0.42 & 0.35 \\
\hline $\mathbf{L U}$ & & & & & & & & & & & 0.75 & 0.81 & 0.77 & 0.11 & 0.78 \\
\hline FUR & & & & & & & & & & & & 0.29 & -0.17 & 0.43 & 0.77 \\
\hline VIS & & & & & & & & & & & & & 0.49 & 0.92 & 0.88 \\
\hline BL & & & & & & & & & & & & & & 0.67 & 0.13 \\
\hline TIND & & & & & & & & & & & & & & & 0.96 \\
\hline
\end{tabular}

+ Trait as defined in Table 2 .

\section{Environmental correlations $\left(r_{E}\right)$}

All possible correlations of environmental correlations between carcass characteristics mostly moderate or high, positiveand negative (Table 4).Falconer and Mackay (1989)they reported some cases, estimates of $\mathrm{r}(\mathrm{G})$ and $\mathrm{r}(\mathrm{E})$ are different in magnitude, or even in sign, while in other cases the two types of correlations are of the same sign and do not differ in magnitude, and a large difference, and particularly a difference in sign, showed that genetic and environmental sources of variation 
affect the characters through different physiological mechanismand this is most common mode of my study.No research is available for estimates of $\left(\mathrm{r}_{\mathrm{E}}\right)$ carcass characteristics in rabbits.

Table 4: Estimates environmental correlations $\left(\mathrm{r}_{\mathrm{E}}\right)$ for carcass characteristics for (NZW) and (BB) rabbits.

\begin{tabular}{|c|c|c|c|c|c|c|c|c|c|c|c|c|c|c|c|}
\hline & WB & WBV & $\mathbf{H C}$ & G & $\mathbf{H}$ & TED & DR1 & DR2 & DR3 & $\mathbf{L U}$ & FUR & VIS & BL & TIND & TIND:TED \\
\hline LWB & 0.96 & 0.91 & 0.38 & 0.70 & 0.46 & 0.82 & -0.68 & 0.17 & 0.88 & 0.04 & 0.72 & 0.73 & -0.19 & 0.79 & -0.49 \\
\hline WB & & 0.77 & 0.59 & 0.42 & 0.71 & 0.68 & -0.01 & -0.97 & -0.94 & 0.28 & 0.37 & 0.53 & 0.61 & 0.85 & 0.66 \\
\hline WBV & & & 0.64 & 0.44 & 0.80 & 0.55 & 0.78 & 0.53 & 0.31 & 0.33 & 0.40 & 0.91 & 0.76 & 0.98 & 0.44 \\
\hline HC & & & & 0.63 & 0.58 & 0.88 & 0.53 & 0.50 & 0.50 & 0.18 & 0.91 & 0.45 & 0.32 & 0.54 & 0.99 \\
\hline G & & & & & 0.69 & 0.94 & 0.54 & 0.95 & 0.97 & 0.99 & 0.85 & 0.58 & 0.75 & 0.61 & 0.34 \\
\hline H & & & & & & 0.61 & 0.23 & 0.83 & 0.92 & 0.83 & 0.25 & 0.35 & 0.55 & 0.55 & 0.55 \\
\hline TED & & & & & & & 0.64 & 0.64 & 0.65 & 0.71 & 0.41 & -0.78 & 0.90 & 0.63 & 0.82 \\
\hline DR1 & & & & & & & & 0.99 & 0.99 & 0.12 & -0.06 & -0.24 & 0.98 & 0.19 & 0.82 \\
\hline DR2 & & & & & & & & & 0.98 & -0.61 & 0.80 & 0.99 & -0.97 & 0.98 & 0.98 \\
\hline DR3 & & & & & & & & & & 0.96 & 0.91 & 0.88 & -0.50 & 0.42 & 0.35 \\
\hline $\mathbf{L U}$ & & & & & & & & & & & 0.75 & 0.81 & 0.77 & 0.11 & 0.44 \\
\hline FUR & & & & & & & & & & & & 0.74 & 0.48 & 0.83 & 0.64 \\
\hline VIS & & & & & & & & & & & & & 0.67 & 0.90 & 0.91 \\
\hline BL & & & & & & & & & & & & & & 0.18 & 0.61 \\
\hline TIND & & & & & & & & & & & & & & & 0.61 \\
\hline
\end{tabular}

+ Trait as defined in Table 2.

Phenotypic correlations $\left(r_{P}\right)$

Estimates of $\left(\mathrm{r}_{\mathrm{P}}\right)$ between records of different carcasscharacteristicswere mainly positive and moderate or high magnitude(Table 5).Hanaa et al., (2014) reported thatdaily weight gain from weaning to slaughter was phenotypically high positive correlated with slaughter weight with value of 0.68 .

However, positive $\left(\mathrm{r}_{\mathrm{P}}\right)$ among any two traits of carcasscharacteristicsdo not necessarily indicate that selecting on one of these trait will lead to an improvement in the other, because a phenotypic correlation is not always a reliable estimate of the genetic relationship existing between traits, for example, environmental effect on two traits could be strong and positively correlated that a negative genetic correlation is masked.Therefore, it is recognized that phenotype association is not a satisfactory guide to the expectedcorrelated genetic response of traits under selection;only geneticcorrelation should be used for such a prediction.In practice, high or moderate and positive estimates of the phenotypic correlation in currentstudies 
and review among carcasscharacteristics give considerable advantage for rabbit breeders in their management and culling decisions.

Table 5: Estimates phenotypic correlations $\left(\mathrm{r}_{\mathrm{P}}\right)$ for carcass characteristics for (NZW) and (BB) rabbits.

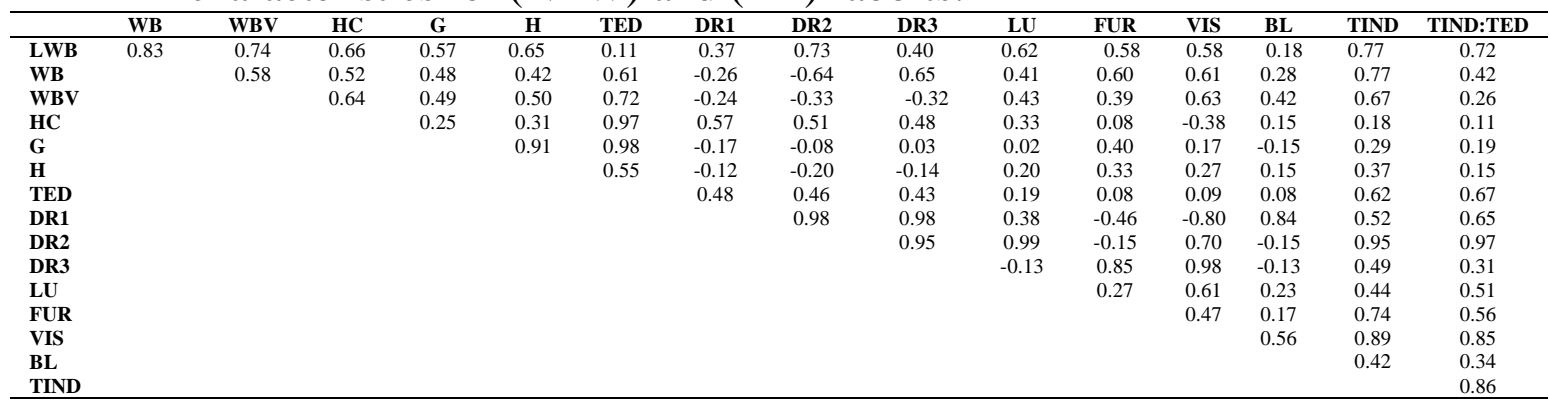

+ Trait as defined in Table 2

\section{Non-genetic affect:}

\section{Breed effect}

Least square means of the carcass characteristics of New Zealand White (NZW) and Baladi Black (BB) were presented on Table 6 shows that in generally there were no significant differences of breed on carcass characteristics except for giblet. New Zealand White had highest of giblet and leaver. Ghosh et al. (2004) reported that no significant differences among breeds in body weight at maturity. Ouyed and Brun (2008) found that there were no significant effects of breed type on commercial carcass weight, commercial carcass yield of New Zealand White and Californian breed and their crosses. Ghosh and Mandel (2008) reported that the effects of breed on the values of hot carcass, giblet, dressed head and total edible were nonsignificant. Baiomy and Hassanien (2011) observed that though breed differences had no significant effect on most carcass traits, dressing yield of carcass was significantly higher in New Zealand white than Californian breed(58.5, 57.3\%), respectively. While Das and Bardoloi (2008) they reported that breed had 
highly significantly $(\mathrm{P}<0.01)$ effects on carcass weight of rabbits and inedible offal and breed did not have a significant effect on edible organs. However Fadare (2015) reported that the New Zealand white had the highest dressing yield percentage of $67.95 \pm 1.95$ while Palomino brown had the least dressing yield (55.23 $\pm 2.36 \%$ ). California and Havana black breed had similar dressing yield.

Table 6. Least-squares means and standard errors of carcass characteristics as affected by breed for New Zealand white (NZW) and Baladi Black (BB) rabbits.

\begin{tabular}{lcc}
\hline Parameters & NZW & BB \\
\hline Live weight, at slaughter, g & $1970.4 \pm 33.5$ & $1956.5 \pm 33.5$ \\
Weight after bleeding, g & $1926.1 \pm 33.7$ & $1910.6 \pm 33.7$ \\
Weight with viscera and without & $1461.6 \pm 18.9$ & $1024.8 \pm 18.9$ \\
head, g & & \\
Edible parts: & & \\
Hot carcass without head, g & $1013.5 \pm 18.9$ & $1024.8 \pm 18.9$ \\
Giblet, g & $107.1 \pm 2.9^{\mathrm{a}}$ & $88.6 \pm 2.9^{\mathrm{b}}$ \\
Head, g & $115.8 \pm 2.1$ & $119.4 \pm 2.1$ \\
Total edible, g & $1236.4 \pm 20.5$ & $1232.9 \pm 20.5$ \\
Dressing yield \%: & & \\
Carcass \% & $51.9 \pm 0.90$ & $52.5 \pm 0.90$ \\
Carcass with giblet \% & $57.3 \pm 0.91$ & $57.1 \pm 0.91$ \\
with giblet and head \% & $58.9 \pm 0.92$ & $59.7 \pm 0.92$ \\
Inedible parts: & & \\
Lung, g & $12.2 \pm 0.41$ & $13.3 \pm 0.41$ \\
Fur, g & $348.5 \pm 11.6$ & $321.1 \pm 11.6$ \\
Viscera, g & $452.0 \pm 19.0$ & $448.0 \pm 19.0$ \\
Blood, g & $40.6 \pm 2.3$ & $41.9 \pm 2.3$ \\
Total inedible & $853.2 \pm 27.6$ & $824.2 \pm 27.6$ \\
Inedible : edible & $69.1 \pm 2.3$ & $68.0 \pm 2.3$ \\
\hline
\end{tabular}

\section{Parity effect:}

In mostly parity affected significantly $(\mathrm{P} \leq 0.01)$ (LBW, SBW, SBWV, SBWN, hot carcass, giblet, total edible, kidney and leaver), the highest value during first parity except for giblet 
and leaver were highest value during second parity. Contrary other traits were insignificantly (Table 7). Whereas Prayaga and Eady (2003). They obtained significantly higher carcass weight in $2^{\text {nd }}$ and $3^{\text {rd }}$ parity litters than in $1^{\text {st }}$ and $4^{\text {th }}$ ones. Ouyed and Brun (2008) reported that there was no significant effect of parity on carcass traits.

Table 7. Least-squares means and standard errors of carcass characteristics as affected by parity for (NZW) and (BB) rabbits.

\begin{tabular}{|c|c|c|c|}
\hline Parameters & $\mathbf{1}^{\text {st }}$ & $2^{\text {nd }}$ & $3^{\text {rd }}$ \\
\hline Live weight, at slaughter, $g$ & $2011.3 \pm 60.8^{\mathrm{a}}$ & $1981.2 \pm 60.8^{\mathrm{ab}}$ & $1936.3 \pm 47.1^{b}$ \\
\hline Weight after bleeding, $g$ & $1975.8 \pm 61.2^{\mathrm{a}}$ & $1926.9 \pm 61.2^{\mathrm{ab}}$ & $1893.1 \pm 47.4^{\mathrm{b}}$ \\
\hline $\begin{array}{l}\text { Weight with viscera and } \\
\text { without head, g }\end{array}$ & $1541.6 \pm 46.3^{\mathrm{a}}$ & $1444.0 \pm 46.3 \mathrm{a}^{\mathrm{b}}$ & $1437.6 \pm 35.9^{\mathrm{b}}$ \\
\hline \multicolumn{4}{|l|}{ Edible parts: } \\
\hline Hot carcass without head, $\mathrm{g}$ & $1071.3 \pm 36.1^{\mathrm{a}}$ & $989.1 \pm 36.7^{\mathrm{b}}$ & $988.3 \pm 27.9^{b}$ \\
\hline Giblet, g & $91.3 \pm 4.7^{\mathrm{a}}$ & $109.4 \pm 4.7^{\mathrm{ab}}$ & $105.3 \pm 3.6^{\mathrm{b}}$ \\
\hline Head, g & $114.1 \pm 3.8$ & $122.6 \pm 3.8$ & $115.6 \pm 3.0$ \\
\hline Total edible, $\mathrm{g}$ & $1276.6 \pm 39.0^{\mathrm{a}}$ & $1221.1 \pm 39.0^{\mathrm{b}}$ & $1209.2 \pm 30.2^{\mathrm{b}}$ \\
\hline \multicolumn{4}{|l|}{ Dressing yield \%: } \\
\hline Carcass $\%$ & $53.4 \pm 1.6$ & $50.5 \pm 1.6$ & $51.3 \pm 1.3$ \\
\hline Carcass with giblet $\%$ & $57.9 \pm 1.7$ & $56.0 \pm 1.7$ & $56.8 \pm 1.3$ \\
\hline $\begin{array}{l}\text { Carcass with giblet and head } \\
\%\end{array}$ & $60.0 \pm 1.7$ & $57.8 \pm 1.7$ & $58.4 \pm 1.3$ \\
\hline \multicolumn{4}{|l|}{ Inedible parts: } \\
\hline Lung, $g$ & $14.2 \pm 0.98$ & $11.4 \pm 0.78$ & $12.3 \pm 0.60$ \\
\hline Fur, $\mathrm{g}$ & $317.2 \pm 34.3$ & $375.8 \pm 21.3$ & $330.4 \pm 16.5$ \\
\hline Viscera, $\mathrm{g}$ & $473.0 \pm 34.3$ & $467.7 \pm 34.3$ & $432.0 \pm 26.6$ \\
\hline Blood, g & $45.4 \pm 4.6$ & $38.1 \pm 4.6$ & $41.1 \pm 3.5$ \\
\hline Total inedible & $843.1 \pm 48.5$ & $886.3 \pm 48.5$ & $835.6 \pm 37.5$ \\
\hline Inedible : edible & $68.4 \pm 4.2$ & $71.3 \pm 4.2$ & $69.2 \pm 3.3$ \\
\hline
\end{tabular}

Season effect:

In generally the effect of season on carcass characteristics in (Table 8)was higher significantly $(\mathrm{P} \leq 0.01)$. Most carcass characteristics were higher in winter months than other seasons, may be attributed to suitability of the environmental conditions to rabbit production, increase in food consumption and abundance of 
green fodders during winter months and summer is more stressful due to extreme heat and relative humidity. Farghaly and ElMahdy (1999), they reported that season appears to be the major non genetic factor affect live body weight and carcass traits. The highest live body weight and carcass traits were estimated during winter. Antonella (2000) reported that the involved mostly the environmental and the season in which temperature play a major role on productive and slaughtering performance. As occurs for livestock, even for rabbits, the increase of environmental temperature over the thermo neutrality value reduces the feed intake and consequently, growth rate resulting in lower slaughter weight, at commerciality slaughter age, and sometimes, better slaughter yield because of the lower proportion of skin, empty cut and offal's.

Table 8. Least-squares means and standard errors of carcass characteristics as affected by season for (NZW) and (BB) rabbits.

\begin{tabular}{lllll}
\hline Parameters & \multicolumn{1}{c}{$\mathbf{1}^{\text {st }}$} & $\mathbf{2}^{\text {nd }}$ & $\mathbf{3}^{\text {rd }}$ & $\mathbf{4}^{\text {th }}$ \\
\hline Live weight, at slaughter, g & $2049.0 \pm 79.0^{\mathrm{a}}$ & $1930.4 \pm 79.8^{\mathrm{b}}$ & $1882.0 \pm 48.0^{\mathrm{b}}$ & $1995.8 \pm 48.0^{\mathrm{b}}$ \\
Weight after bleeding, g & $2046.5 \pm 79.0^{\mathrm{a}}$ & $1898.7 \pm 79.6^{\mathrm{b}}$ & $1833.2 \pm 48.3^{\mathrm{b}}$ & $1949.4 \pm 48.3^{\mathrm{b}}$ \\
Weight with viscera and without head, g & $1505.9 \pm 46.9$ & $1019.4 \pm 46.9$ & $1024.4 \pm 28.4$ & $1024.4 \pm 28.4$ \\
Edible parts: & & & & \\
Hot carcass without head, g & $995.4 \pm 46.9$ & $1019.4 \pm 46.9$ & $1025.6 \pm 28.4$ & $1024.4 \pm 28.4$ \\
Giblet, g & $137.9 \pm 6.1^{\mathrm{a}}$ & $91.1 \pm 6.1^{\mathrm{b}}$ & $92.2 \pm 3.7^{\mathrm{b}}$ & $86.8 \pm 5.7^{\mathrm{b}}$ \\
Head, g & $126.0 \pm 5.0^{\mathrm{a}}$ & $107.5 \pm 5.0^{\mathrm{b}}$ & $114.0 \pm 3.0^{\mathrm{b}}$ & $122.2 \pm 3.0^{\mathrm{a}}$ \\
Total edible, g & $1259.2 \pm 50.6^{\mathrm{a}}$ & $1218.0 \pm 50.6^{\mathrm{b}}$ & $1231.9 \pm 30.7^{\mathrm{ab}}$ & $1233.4 \pm 30.7^{\mathrm{ab}^{\mathrm{b}}}$ \\
Dressing yield \%: & & & & \\
Carcass \% & $48.1 \pm 2.1^{\mathrm{b}}$ & $52.7 \pm 2.1^{\mathrm{b}}$ & $54.8 \pm 1.3^{\mathrm{a}}$ & $51.4 \pm 1.3^{\mathrm{b}}$ \\
Carcass with giblet \% & $54.7 \pm 2.2^{\mathrm{b}}$ & $57.5 \pm 2.2^{\mathrm{b}}$ & $59.8 \pm 1.3^{\mathrm{a}}$ & $55.7 \pm 1.3^{\mathrm{b}}$ \\
Carcass with giblet and head \% & $55.3 \pm 2.2^{\mathrm{b}}$ & $59.4 \pm 2.2^{\mathrm{b}}$ & $61.9 \pm 1.3^{\mathrm{a}}$ & $58.6 \pm 1.3^{\mathrm{b}}$ \\
Inedible parts: & & & \\
Lung, g & $9.9 \pm 1.0^{\mathrm{b}}$ & $14.6 \pm 1.0^{\mathrm{a}}$ & $12.1 \pm 0.61^{\mathrm{ab}}$ & $13.8 \pm 0.61^{\mathrm{ab}}$ \\
Fur, g & $418.6 \pm 27.6^{\mathrm{a}}$ & $301.7 \pm 27.6^{\mathrm{b}}$ & $325.2 \pm 16.8^{\mathrm{b}}$ & $319.0 \pm 16.8^{\mathrm{b}}$ \\
Viscera, g & $518.2 \pm 44.6^{\mathrm{a}}$ & $442.2 \pm 44.6^{\mathrm{b}}$ & $395.6 \pm 27.1^{\mathrm{b}}$ & $474.2 \pm 27.1^{\mathrm{ab}}$ \\
Blood, g & $39.8 \pm 6.0$ & $45.1 \pm 6.0$ & $36.8 \pm 3.6$ & $44.4 \pm 3.6$ \\
Total inedible & $995.3 \pm 63.0^{\mathrm{a}}$ & $812.4 \pm 63.0^{\mathrm{b}}$ & $751.9 \pm 38.2^{\mathrm{c}}$ & $860.3 \pm 38.2^{\mathrm{b}}$ \\
Inedible : edible & $76.7 \pm 5.5^{\mathrm{a}}$ & $69.2 \pm 5.5^{\mathrm{a}}$ & $61.3 \pm 3.3^{\mathrm{b}}$ & $71.3 \pm 3.3^{\mathrm{a}}$ \\
\hline
\end{tabular}

\section{CONCLUSION:}

From the values of the moderate or high for hertabilities, it is genetic point of view improvements were achieved in carcass traits through selection of animals.Common litter effects 
appeared to have strong effects on carcass characteristics.Genetic, common litter, environmental correlations amongrecords ofcarcasscharacteristics were mostly moderate or high, positiveindicate that selecting on one of these trait will lead to an improvement in the other.No significant differences of breed on carcass characteristics. Mostly parity affected significantly on carcass characteristics.Most carcass characteristics were higher in winter months than other seasons 


\section{REFERENCES:}

Adelodun Opeyemi Fadare (2015).Carcass Traits of New Zealand White, Californian, Palomino Brown and Havana Black Rabbit In the Humid TropicsJournal of Agriculture and Veterinary Science Volume 8, Issue 3 Ver. I, PP 19-23.

Al-Saef, A.M., Khalil, M.H., Al-Homidan, A.H., Al-Dobaib, S.N., Al-Sobayil, K.A.(2007).Carcass, lean composition and meat quality traits in new Saudi synthetic lines of rabbitsdeveloped to be adaptable tohot climates.3rd International Conference of Quantitative Genetics, Zhejiang University, Hangzhou, China, August 19-2.

Antonella Dallae Zotte (2000).Main factors influencing the rabbit carcass and meat qualityConference: 7th World Rabbit Congress, Volume: A

Ayyat, M.S., Anous, M.R.andSadek,M.H. (1994). Genetic parameters for meat production in rabbits. 1. Non carcass components. World RabbitScience,2(3): 93-99.

Baiomy, A.A. and Hassanien, H. H. M.(2011).Effect of breed and sex on carcass characteristics and meat chemical composition of New Zealand white and Californianrabbits under upper Egyptianenvironment. Egyptian Poultry Science 31 (2): 275-284.

Bianospino E., Wechsler F.S., Fernandes S., Roça R.O., Moura A.S.A.M.T. (2006). Growth, carcass and meat quality traits of straight bred and crossbred Botucatu rabbits. World Rabbit Sci. 14: 237-246.

Boldmann, K. G.; Kriese, L. A.; Van Tassell, C. P.; Kachman, S. D. (1995). A manual for use of MTDFREML. A set programs to obtain estimates of variances and covariance [DRAFT]. U.S. Department of Agriculture, Agricultural Research Service, USA. 
Das S.K. and Bardoloi R.K. (2008). Study on the factors affecting carcass traits of broiler rabbits in eastern Himalayanregion of IndiaWorld Rabbit Sci. 16: 107 110.

Farghaly H M and El-Mahdy M R M (1999).Genetic and nongenetic factors affecting live, carcass and non-carcass traits of New Zealand White rabbits in Egypt. Indian Journal of Animal Science 69(8): 596-603.

Ferraz, J. B. S.; Johnson, R. K.; Van Vleck, L. D. (1992).Estimation of genetic trends and genetic parameters for reproductive and growth traits of rabbits raised in subtropics with animal model. J. Applied Rabbit Research, 15:131-142.

Ferraz, J.B.S.andEler, J.P. (1996). Comparison of animal models for estimation of (co)variance components and genetic parameters of reproductive, growth and slaughter traits of Californian and New Zealand rabbits raised under tropical conditions. Proceedings of $6^{\text {th }}$ World Rabbit Congress, Vol 2: 279-284. Toulouse, France.

Garreau H., Licois D., Rupp R., Rochambeau H. de (2006).Genetic variability of the resistance to epizooticrabbit enteropathy(ERE): new results. InProc. $8^{\text {th }}$ World. Cong. Appl. Livest. Prod.,Belo Horizonte, Brazil.

Garreau H.; Eady S.J.;,Hurtaud J., Legarra A. (2008).Genetic parameters of production traits and resistance to digestive disorders in a commercial rabbit population. $9^{\text {th }}$ World Rabbit Congress - June 10-13Verona- Italy

Ghosh N. and Mandal L. (2008).Carcass and meat quality traits of rabbits.(Oryctolaguscuniculus) under warm-humid 
condition of West Bengal, India. Livestock Research for Rural Development 20 (9)[7].

Ghosh, S. K.; Das, A.; Bujarbaruah, K. M.; Das, Asit; Dhiman, K. R. and Singh, N. P. (2004).Studies on the productive and reproductive performances of Soviet Chinchilla and New Zealand White breeds of rabbit under the subtropical condition of Tripura. In: Proceeding 8th World Rabbit Congress, 7-10 September, Puebla, Mexico, 1188 -1193.[8].

Hanaa A, El-Raffa A, Shebl MK, El-Delebshany A, El-Sayed N (2014). Genetic evaluation of some economic traits in a maternal line of rabbits. Egyptian Journal of Poultry Science 34:85-98.

Horsted K, Allesen-Holm BH, Hermansen JE (2010). The effect of breed and feed-type on the sensory profi le on breast meat in male broilers reared in an organic freerange system. British Poultry Science 4:515-524.

Khalil MH, Shebl MK, Kosba MA, El-Sabrout K, Zaki N (2016). Estimate the contribution of incubation parameters influence egg hatchability using multiple linear regression analysis. Veterinary World 9:806-810.

Metzger S., Odermatt M., Szendro Z., Mohaupt M., Romvari R., Makai A, Biro-Nemeth E. , Sipos L. Radnai I., Horn P. (2006). A study of the carcass traits of different rabbit genotypes.World Rabbit Science, 14: $107-114[9]$.

Lebas F, Coudert P, Rouvier R, De Rockambeau H (1986).The Rabbit: Husbandry, Health and Production. F.A.O., U.N, Rome, Italy.

Lukefahr, S.D., Odi, H.B.andAtakora, J.K.A.(1996).Mass selection for 70 day body weight in rabbits. Journal of Animal Science,74: 1481-1489. 
Ouyed A. and BrunJ.M.(2008).Heterosis, direct and maternal additive effects on rabbit growth and carcass characteristics. In Proc: 9th World Rabbit Congress June 10-13, 2008 -Verona -Italy 195-200[1].

Parig-Bini R., Xiccato G., Cinetto M., DalleZotte A. (1992).Effect of age, slaughter weight and sex on carcass and meat quality of rabbit. Anim. Breed Abst., 61: 257.

Prayaga, K. C. and Eady, S. J. (2003). Performance of purebred and crossbred rabbits in Australia: Individual growth and slaughter traits. Australian Journal Agriculture Research, 54: 159 - 166.

Roiron A., Ouhayoun J., Delmas D. (1992).Effect of body weight and age at slaughter on carcass and meat quality of rabbit. Anim. Breed Abst., 61: 64.

SAS., (2003). SAS OnlineDoc 9.13 SAS Institute Inc.,Cary, NC, USA.

Su G., Kjaer J.B., Brenøe U.T., Sørensen P. (1999). Estimates of genetic parameters in Danish white rabbits using an animal model: I. Growth and carcass traits. World Rabbit Sci., 7, 59-64. 
